University of Nebraska - Lincoln

DigitalCommons@University of Nebraska - Lincoln

\title{
A Single Nucleotide Polymorphism in the Bovine Kit Oncogene (Hardy-Zuckerman 4 Feline Sarcoma Viral (v-kit) Oncogene Homolog)
}

\author{
M. D. Grosz \\ USDA-ARS, grosz@larrl.ars.usda.gov \\ R. T. Stone \\ USDA-ARS
}

Follow this and additional works at: https://digitalcommons.unl.edu/hruskareports

Grosz, M. D. and Stone, R. T., "A Single Nucleotide Polymorphism in the Bovine Kit Oncogene (Hardy-Zuckerman 4 Feline Sarcoma Viral (v-kit) Oncogene Homolog)" (1999). Roman L. Hruska U.S. Meat Animal Research Center. 224.

https://digitalcommons.unl.edu/hruskareports/224

This Article is brought to you for free and open access by the U.S. Department of Agriculture: Agricultural Research Service, Lincoln, Nebraska at DigitalCommons@University of Nebraska - Lincoln. It has been accepted for inclusion in Roman L. Hruska U.S. Meat Animal Research Center by an authorized administrator of DigitalCommons@University of Nebraska - Lincoln. 


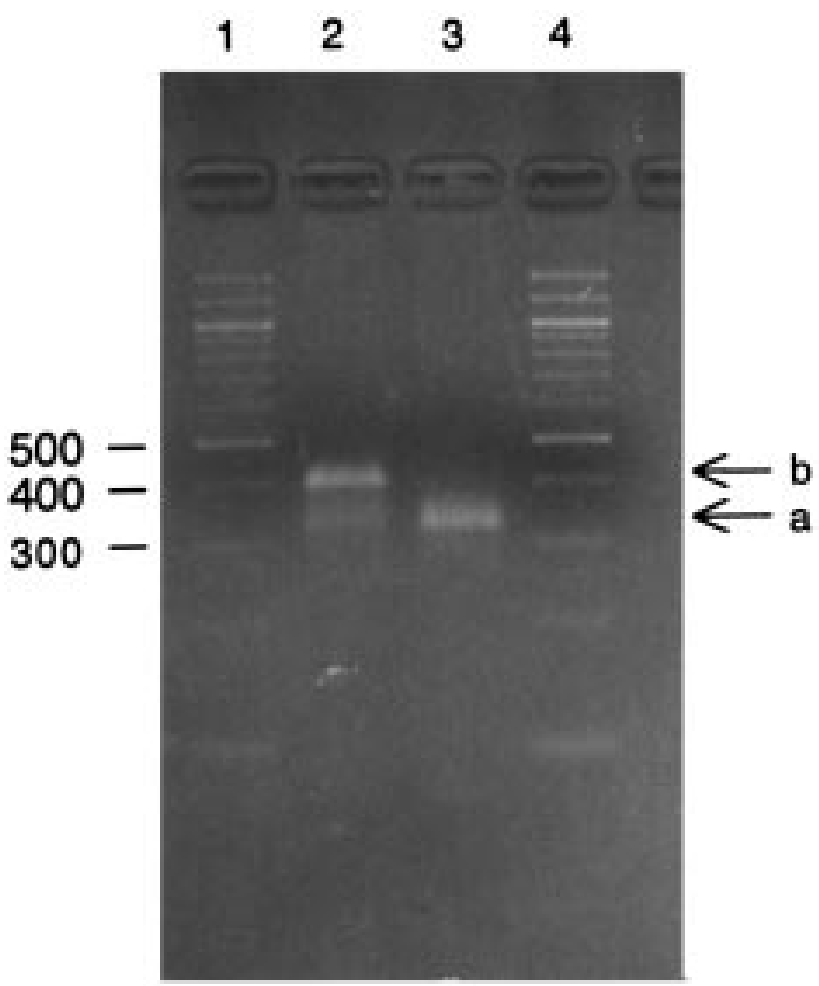

Fig. 1. Heterozygote (a/b; lane 2) and homozygote (a/a; lane 3) for kit SNP. Size standards (100 bp ladder, NEB) are in lanes 1 and 4.

\section{A single nucleotide polymorphism in the bovine kit oncogene (Hardy-Zuckerman 4 feline sarcoma viral (v-kit) oncogene homolog) M D Grosz ${ }^{1}$, R T Stone ${ }^{2}$}

${ }^{1}$ USDA-ARS, Fort Keogh Livestock and Range Research Laboratory, Route 1 Box 2021, Miles City, MT 59301 USA; ${ }^{2}$ USDA-ARS, Roman L. Hruska US Meat Animal Research Center, Clay Center, NE 689330166 USA

Accepted 14 May 1999

Source/description: Oligonucleotide primers were designed from the bovine Kit cDNA sequence (acc. D16680). Exon and intron boundaries were determined by comparison with the human KIT genomic sequence (acc. U63834).

PCR conditions and SNP analysis: Twelve microliter reactions were performed in microtiter plates with the following conditions: $80 \mathrm{ng}$ genomic DNA, $50 \mathrm{~mm} \mathrm{KCl,} 2.5 \mathrm{~mm} \mathrm{MgC1}_{2}, 10 \mathrm{~mm}$ Tris-HC1 $\mathrm{pH}=9 \cdot 0,30 \mu \mathrm{M}$ each of unlabeled dNTP, $0 \cdot 4 \mu \mathrm{M}$ each of two oligonucleotide primers, and 0.35 units of Taq polymerase. The PCR profile was $3 \mathrm{~min}$ at $92^{\circ} \mathrm{C}$, followed by 35 cycles of $92^{\circ} \mathrm{C}$ for $30 \mathrm{~s}$, $58^{\circ} \mathrm{C}$ for $30 \mathrm{~s}$, and $72^{\circ} \mathrm{C}$ for $30 \mathrm{~s}$. PCR products were digested with restriction endonuclease PstI for $1 \mathrm{~h}$ after amplification using specifications provided by the supplier. Resulting DNA fragments were electrophoresed through $3 \cdot 0 \%$ agarose gel, stained with ethidium bromide, and photographed.

Polymorphism: Two alleles have been identified ('a' and 'b', Fig. 1).
In a survey of 26 unrelated animals, allele 'b' was identified in one animal, which was heterozygous (therefore, frequencies of ' $a$ ' and ' $b$ ' are 0.98 and 0.02 , respectively).

Inheritance: No deviation from codominant Mendelian inheritance was observed in 36 meioses.

Chromosomal location: KIT has been localized to bovine chromosome 6 by previous linkage (RFLP) $^{1}$ and somatic cell hybrid analysis $^{2}$. This reported SNP has been used to place KIT on bovine chromosome 6, between BM4621 and BM415. Based on the limited number of meioses, CRIMAP was unable to determine the more likely order between BM4621-KIT-CA028-BM415 and BM4621CA028-KIT-BM415.

References

1 Barendse W. et al. (1997) Mamm Genome 8, 21-28.

2 Zhang N. et al. (1992) Genomics 14(1), 131-6.

Correspondence: M D Grosz (e-mail: grosz@larrl.ars.usda.gov). 